\title{
Remazol Black Dye Degradation by Bacillus Endophyticus
}

\author{
Munesh Kumari $^{1}$, Swaranjit Singh Cameotra ${ }^{1}$, Maulin P Shah ${ }^{2 *}$ \\ ${ }^{1}$ Institute of Microbial Technology, Sector 39A, Chandigarh-160036, India \\ ${ }^{2}$ Industrial Waste Water Research Lab, Division of Applied \& Environmental Microbiology \\ Enviro Technology Limited, India \\ *shahmp@beil.co.in
}

\begin{abstract}
Most of the dyes containing azo groups are discharged into wastewater streams lacking of any pretreatment and pollute water and soil environments. To thwart pollution of our prime resources, elimination of these dyes containing impurity is of enormous significance. For this principle, wastewater samples were brought to gather from dye-contaminated sites of India. About 14 bacterial isolates were isolated through enrichment and then tested for their potential to remove Remazol Black-B azo dye in liquid medium. Isolate 1, 2 \& 3 having competence to degrade Remazol Black-B proficiently were screened on modified mineral salt medium. Isolate 1 was competent to absolutely remove the dye from the liquid medium in $10 \mathrm{~h}$. The isolate proved the most excellent performance at the dye concentration of $150 \mathrm{mg} \mathrm{L}^{-1}$ medium (pH 7.5) and at temperature $37^{\circ} \mathrm{C}$. Similarly, yeast extract proved to be the best carbon source for decolorization purpose. The results imply that the isolate 1 could be used for the removal of the reactive dyes from textile effluents.
\end{abstract}

Keywords: Azo dyes, Remazol Black-B, Wastewater, Yeast extract, Bacillus endophytics.

\section{INTRODUCTION}

Effluent discharged from the textile industries has variable characteristics in terms of $\mathrm{pH}$, dissolved oxygen, organic, and inorganic chemical content, etc. Together with industrialization, awareness towards the environmental problems arising due to effluent discharge is of critical importance. Pollution caused by dye effluent is mainly due to durability of the dyes in wastewater (1). Existing effluent treatment procedures utilize $\mathrm{pH}$ neutralization, coagulation followed by biological treatment, but they are unable to remove recalcitrant dyes completely from effluents. This is because of the color fastness, stability, and resistance of dyes to degradation (2). Bioremediation is the microbial clean up approach, microbes can acclimatize themselves to toxic wastes and new resistant strains develop naturally, which can transform various toxic chemicals to less harmful forms. Several reports have suggested that the degradation of complex organic substances can be brought about by bacterial enzymes (3-8). Different dyes used in textile industry usually have a synthetic origin and complex aromatic molecular structures which make them more stable and more difficult to be biodegraded. Due to their ease of manufacturing methodology, azo dye accounts for almost $80 \%$ of annual production of commercial dyes all over the world. There are over 10, 0000 commercially available dyes with a production of over $7 x^{105}$ tons per year (9). Azo dyes, containing one or more azo bond ($\mathrm{N}=\mathrm{N}-$ ), account for $60-70 \%$ of all textile dyestuffs used. It is estimated that about $10-15 \%$ of the total production of colorants is lost during their synthesis and dyeing Processes $(10,11)$. Whereas, in the case of reactive dyes almost $50 \%$ of the initial dye load is found in the dye bath effluents. Colored industrial effluent is the most obvious indicator of water pollution and the discharge of highly colored synthetic dye effluents is aesthetically displeasing and cause considerable damage to the aquatic life. Although several physical-chemical methods have been used to eliminate the colored effluents in wastewater, they are generally expensive, produce large amounts of sludge. More often these conventional modes of treatment lead to the formation of some harmful side products. Interest is therefore now focused on the microbial biodegradation of dyes as a better alternative (12). Some microorganisms, including bacteria, fungi and algae, can degrade or absorb a wide range of dyes (13). The biological mode of treatment of dye bath effluents offers distinct advantages over the conventional modes of treatment. This method is more economical and leads to less accumulation of relatively harmless sludge. Most importantly, biological treatment of dye bath effluents is eco friendly. It causes mineralization of dyes to simpler inorganic compounds which are not lethal to life 
forms. The basic step in the decolorization and degradation of azo dyes is breakdown of azo bonds, leading to removal of color. Azo dyes are known to undergo reductive cleavage whereas the resultant aromatic amines are metabolized under aerobic conditions (14). So for complete mineralization of azo dyes the microbial population forming part of treatment system should be able to work efficiently. In view of these problems the most potent bacterial culture was selected in this study for maximum decolorization of Remazol Black B being selected.

\section{MATERIALS AND MethodS}

\subsection{Waste Water Sample Analysis}

Ankleshwar, Gujarat, India is one of the most industrialized cities in India. It is ideal for waste water sample collection. The sample was collected from the center point of the vicinity. The Temperature and $\mathrm{pH}$ were analyzed at the site. The temperature was analyzed using laboratory grade thermometer and $\mathrm{pH}$ was analyzed by using $\mathrm{pH}$ meter (Hanna digital $\mathrm{pH}$ meter). The sample was transferred to laboratory at $4^{\circ} \mathrm{C}$ as per the standard methods (24). The physicochemical parameters such as Color, Biological Oxidation Demand, Chemical Oxygen Demand, Total Suspended Solids, and Total Dissolved Solids were analyzed as soon as the sample was brought to the laboratory. Sample color was analyzed by spectrophotometer (SHIMADZU UV-1700). BOD was determined by employing evaporation method by dissolve oxygen meter while chemical oxygen demand was measured by instrument directly.

\subsection{Isolation of Bacterial Culture}

The bacterial strains were isolated from activated sludge containing wastewater treatment plant. Inoculum developed from the isolates was first enriched using a modified MSM medium with Remazol Black-B dye as the source of C and N (20). Remazol Black B dye was added to a concentration of $150 \mathrm{mg} \mathrm{L}^{-1}$. The cultures containing $200 \mathrm{ml}$ MSM with a dye broth in $500 \mathrm{ml}$ Erlenmeyer flasks were inoculated with $10 \mathrm{ml}$ volume of activated sludge. The flasks were incubated at $37{ }^{\circ} \mathrm{C}$ for 5 days in static conditions. After incubation, the cell suspensions from each vial were plated on MSM agar medium and incubated at $37{ }^{\circ} \mathrm{C}$ for $24 \mathrm{~h}$. Microbial colonies that appeared on the agar medium were washed gently with sterile water and resuspended in flasks containing fresh MSM broth enriched with the dye. Approximately 14 colonies actively growing were selected for purification.

\subsection{Identification of Isolates by 16s Rrna Gene Sequencing Method}

For 16S rRNA gene sequencing, DNA was isolated using the bacterial DNA isolation kit (Fungal/Bacterial/DNA Miniprep Kit, Zymo Research). The 16S rRNA gene was amplified by PCR using universal bacterial primers 27F (5'AGAGTTTGATCCTGGCTCAG-3') and 1492R (5'TACGGYTACCTTGTTACGACTT-3'). The PCR product was purified using a QIA quick PCR purification kit (Qiagen) and sequenced using an ABI PRISM model 3700 automatic DNA sequencer and Big Dye Terminator cycle sequencing kit (Applied Biosystems). The 16S rRNA gene sequences of isolates were subjected to NCBI BLAST sequence similarity search (Altschul et al., 1990) and EzBioCloud (Kim et al., 2012) to identify the nearest taxa.

\subsection{Purification of Bacterial Isolates}

Isolated isolates were purified by streaking on agar containing MSM medium at $20 \mathrm{~g} \mathrm{~L}^{-1}$ concentration. Streaking was done thrice in Zig-zag manner. The purified cultures were preserved in a refrigerator for subsequent study.

\subsection{Screening}

Using modified MSM medium, screening was completed to obtain proficient bacterial strains able to decolorize the azo dye. For this purpose, 14 isolates obtained the talent to decolorize Remazol BlackB from all samples was selected. Ability of each isolated isolates was tested in liquid medium after decolorization process. Inoculated Media were incubated at $37^{\circ} \mathrm{C}$ for $24 \mathrm{~h}$ with respective inoculum. After $24 \mathrm{~h}$, harvesting of the cells was done by centrifugation at 10,000 rpm (REMI R-23, India) for 10 minutes. Then decolorization was concluded with the facilitate of spectrophotometer (SHIMADZU-1700, Japan) at $597 \mathrm{~nm}$. Uninoculated blanks were run to confirmed abiotic decolorization. The three major effectual bacterial isolates $(1,2 \& 3)$ from the concluding screening were again scrutinized for their decolorization potentials in test tubes at diverse time intervals. $0.5 \%$ 
yeast extract as a co-substrate were added in ten milliliters sterilized MSM broth containing azo dye (Remazol Black B) at $150 \mathrm{mg} \mathrm{L}^{-1}$ concentration. Uniform cell density of the inocula were added with respective bacterial strains at (OD: 0.6) $597 \mathrm{~nm}$. Azo dye containing MSM medium with yeast extract in uninoculated test tubes were incubated under parallel environment to make sure for abiotic decolorization of dye. Decolorization was measured after every $6 \mathrm{hrs}$ interval up to $24 \mathrm{hrs}$ at $597 \mathrm{~nm}$ by spectrophotometer as described by Khalid et al. (2008).

\subsection{Environmental Parameters Optimization}

Distinctive manner of parameters like substrate concentration, temperature and $\mathrm{pH}$ were optimized during the performing tests for distinct carbon sources (Mannitol. Yeast extract, glucose, maltose) at 5 $\mathrm{g} \mathrm{L}^{-1}$ concentration were explored as co- substrate in the dye removal development. Optimization studies have involved the selection of the concentration of the dye $(50,75,100,125,150,200$ and 250 $\left.\mathrm{mg} \mathrm{L}^{-1}\right)$, the temperatures $\left(25,30,35,40,45^{\circ} \mathrm{C}\right)$ and $\mathrm{pH}(5,6,7,8,9)$. Isolated strains $1,2 \& 3$ have been with in order to optimize their color removal competence. As culture conditions were the unchanged as used in color removal experiment i.e., $100 \mathrm{mg} \mathrm{L}^{-1}$ of Remazol Black-B azo dye with MSM was used. Uninoculated blanks were run to make sure the abiotic decolorization throughout the experimentation.

\subsection{Statistical Analysis}

Data were entered in a Microsoft $®$ Excel 2007 spreadsheet.

\section{RESULTS}

To scrutinize the color potency depth of the azo dye Remazol Black-B decolorizing activity by an effectual bacterial isolates, liquid medium was used. Based on the relative aptitude of the decolorization of diverse isolates, three most excellent performing bacterial isolates $(1,2 \& 3)$ with more than $90 \%$ of decolorizing activity were preferred for more experiments (Data not shown).

\subsection{Biodecolorization of Remazol Black-B by Selected Bacterial Isolates}

Microbial decolorization of Remazol Black-B by the most promising selected bacterial isolates $(1,2$ \& 3) was corroborated by performing one more experiment in liquid medium at distinctive time frame (Figure 1). It was surveyed that distinctive bacterial isolates had patchy aptitude to eliminate Remazol Black-B in actively growing cultures. The most competent bacterial isolate to decolorize Remazol black-B colorless was by isolate 1 with $98 \%$ color degrading efficiency in $10 \mathrm{~h}$ incubation interlude while left over isolates exhibited utmost decolorization in $16 \mathrm{~h}$. Isolate 2 was the second largely skilled bacterial isolate and it removes the color of Remazol Black-B up to $94 \%$ in 16 h. Similarly, C isolates had decolorization potential of $86 \%$.

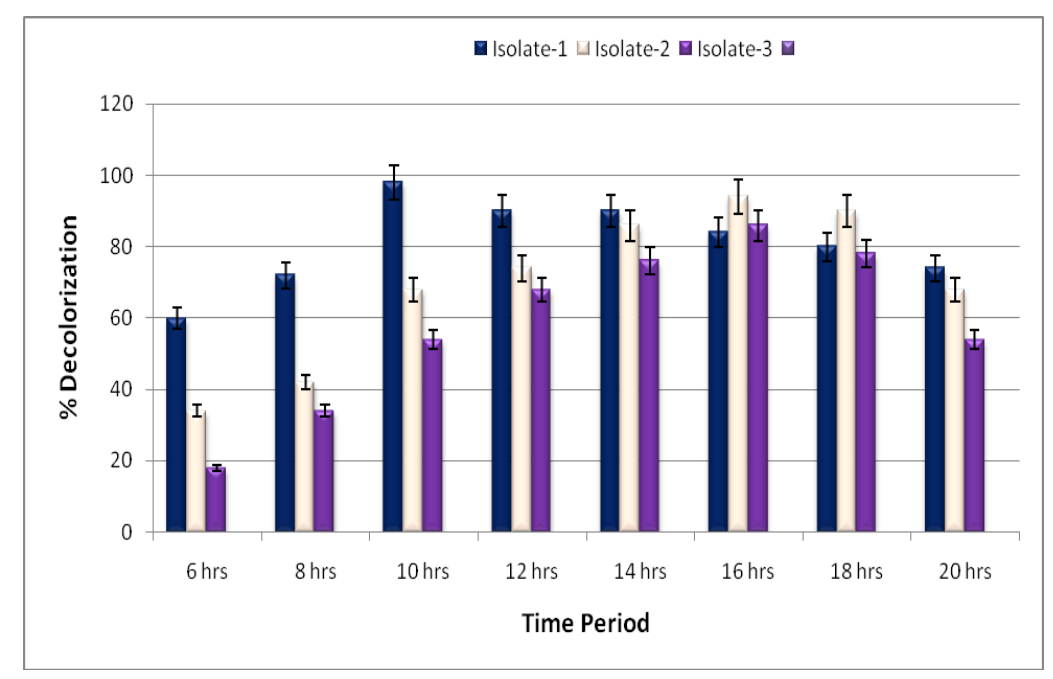

Fig.1 Biodecolorization of Remazol Black $-B$

\subsection{Identification}

Sequence analysis of $16 \mathrm{~S}$ rDNA showed that isolate 1 had utmost resemblance with the species Bacillus spp (96\%) which has been proved to have decolorizing ability against azo dyes. Based on the phenotypic \& genotypic characteristics analysis, isolate 1 was identified as Bacillus endophytics 


\subsection{Factors affecting Biodecolorization of Remazol Black-B in Liquid Medium}

Potential of selected isolates $(1,2$, and 3) was further explored for the optimization of assorted incubation/ environmental circumstances for removal of the azo dye in liquid medium. It was apparent (Figure 2) that Remazol Black-B azo dye decolorization piercingly improved up to $100 \mathrm{mg} \mathrm{L}^{-1}$ of substrate concentration and utmost removal was observed at $100 \mathrm{mg} \mathrm{L}^{-1}$ of substrate concentration. Then, there was a slow but sure decline in the azo dye decolorization. Isolate 1 was the most proficient azo dye removal strain with more or less complete removal of the color i.e., $100 \%$ decolorization at $100 \mathrm{mg} \mathrm{L}^{-1}$ and minimum decolorization was recorded at $50 \mathrm{mg} \mathrm{L}^{-1}$ while after $100 \mathrm{mg} \mathrm{L}^{-1}$ substrate concentration, again 1 showed a decreasing trend. Isolate 2 was the second at the rank with $90 \%$ decolorization at $100 \mathrm{mg} \mathrm{L}^{-1}$. But, 3 showed different trend from the other isolates, it indicated enhanced decolorization up to $200 \mathrm{mg} \mathrm{L}^{-1}(82 \%)$.

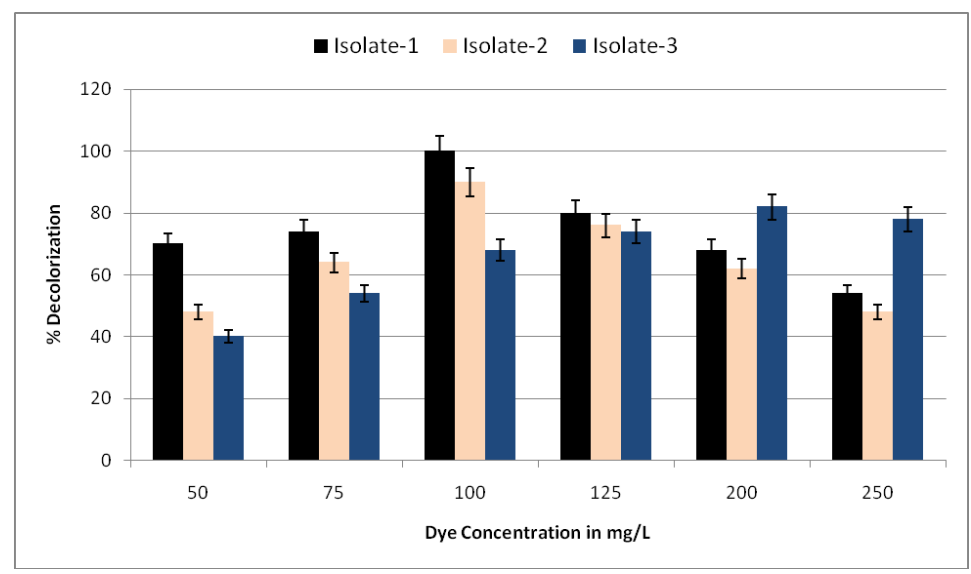

Fig 2. Effect of Substrate Concentration

\subsection{Carbon Source Effect}

Sound effects of distinctive carbon sources such as maltose, mannitol, glucose and yeast extract were assessed on Remazol Black-B decolorization by bacterial isolates (Figure 3). It was noted that utmost decolorization take place with 5\% yeast extract in all selected strains (85 to 98\%) that was pursued by glucose in which decolorization takes place in the range of 20 to $25 \%$. However, slightest decolorization was perceived in the circumstances of mannitol (10 to $15 \%)$. Likewise, maltose function also demonstrated decolorization in the poorer range (up to $18 \%$ ).

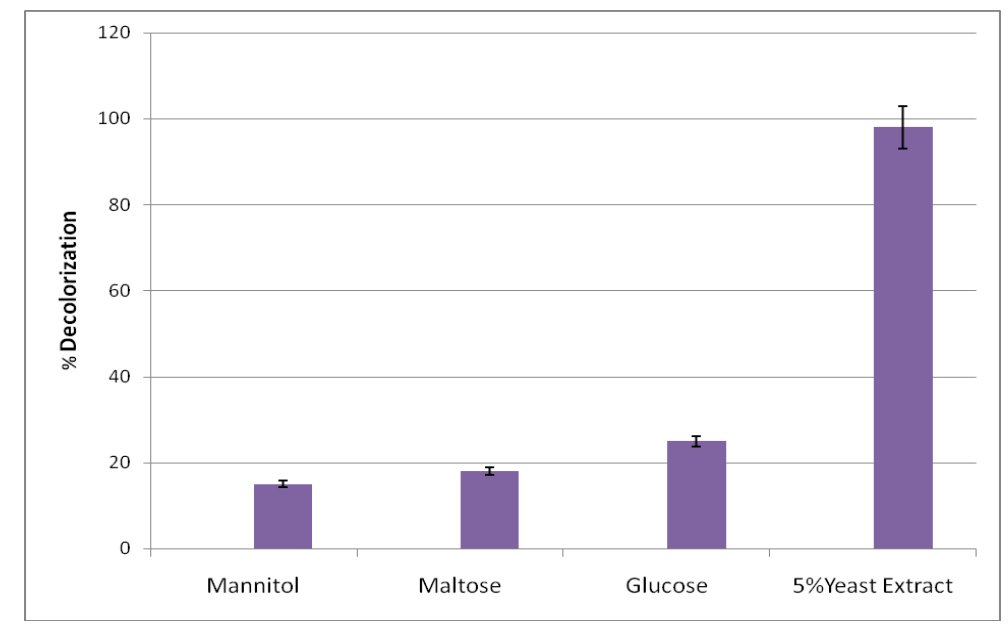

Fig 3. Effect of different Sources of carbon on decolorization of Ramazol Black-B

\section{5.pH Effect}

To optimize the $\mathrm{pH}$ value study, distinctive degree of $\mathrm{pH}$ ranging from 5 to 9 were exploited and all selected isolates were inoculated at these levels (Figure 4). To begin with the enhance in $\mathrm{pH}$ range from 5 to 7, decolorization improved and utmost decolorization take place at $7.5 \mathrm{pH}$. Likewise, auxiliary raise in $\mathrm{pH}$ from 7 to 9 had pessimistic outcome on decolorization aptitude of a mixture of isolates. The peak decolorization was observed with the isolate $1(98 \%)$ at $\mathrm{pH} 7.5$ though least decolorization take place at $\mathrm{pH}$ 9. Comparable tendency in lingering isolates 2 and 3 were examined 
at $\mathrm{pH}$ 7.5. Overall, it was noted that all the bacterial isolates demonstrated most favorable decolorization from $\mathrm{pH} 5$ to 7.5 .

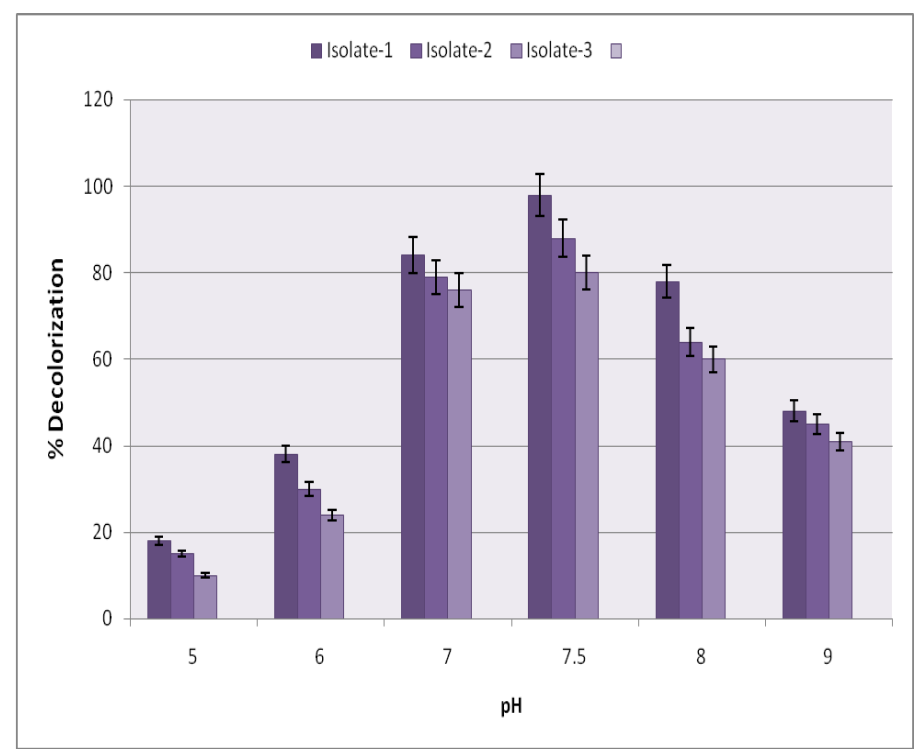

Fig 4. Effect of $p H$ on decolorization of Ramazol Black-B

\subsection{Incubation Temperature Effect}

Five levels $\left(25,30,35,40\right.$ and $\left.45{ }^{\circ} \mathrm{C}\right)$ of the temperature used for the assessment of optimum biodecolorization Remazol Black - B by selected bacterial isolates. It is apparent (Figure 5), when the temperature is raised from 25 to $35{ }^{\circ} \mathrm{C}$ there was an inconsistent trend in decolorization due to different isolates. Isolate one and two showed gradual increase in decolorization, while isolate three indicated maximum decolorization at $25{ }^{\circ} \mathrm{C}$. Other two bacterial isolates $(1$ and 2$)$ with a gradual increase from 25 to $35{ }^{\circ} \mathrm{C}$ showed maximum decolorization at $35^{\circ} \mathrm{C}$. As the temperature is further raised from $35{ }^{\circ} \mathrm{C}$ to $45{ }^{\circ} \mathrm{C}$, there was sharp decline in decolorization capacity in all isolates which was also observed that when the temperature, abiotic decolorization also increased. Utmost decolorization was detected with the isolate $1(98 \%)$ at $35^{\circ} \mathrm{C}$ and is followed by isolate $2(94 \%)$ at the similar temperature. Least decolorization was observed at $45^{\circ} \mathrm{C}$ in all selected isolates.

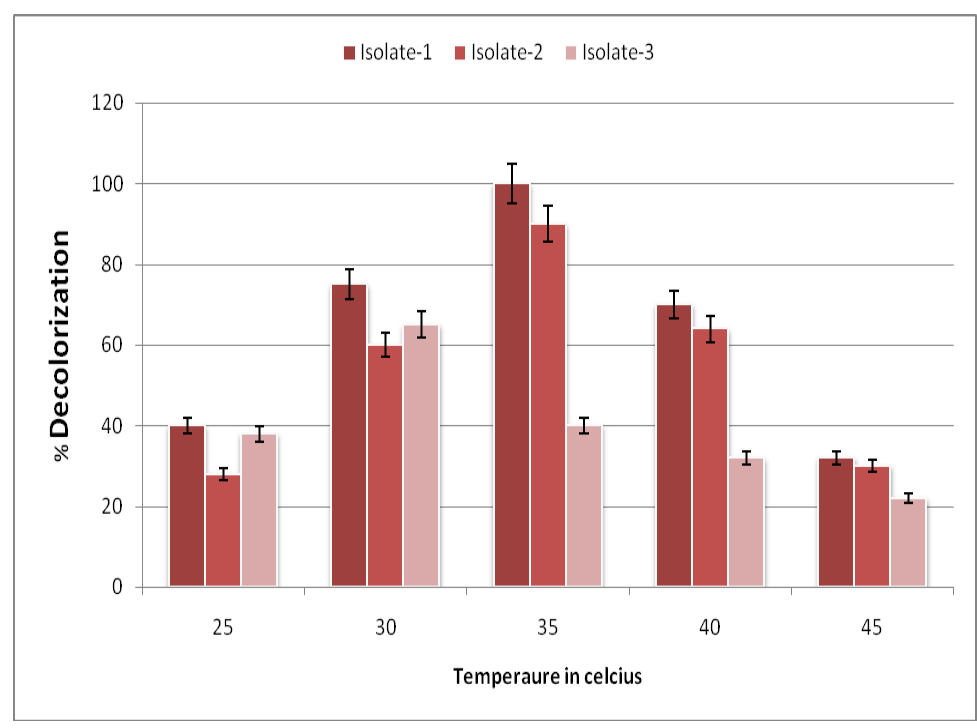

Fig 5. Effect of incubation temperature

\section{DisCUSSION}

Industrial effluent is very much unstable and it fluctuates repeatedly in an ample assortment depending upon the course practiced. Most of the south Asian countries have rigorous environmental trouble due to hasty industrialization development. This observable fact is very widespread where the polluting industries like paper, pulp, textile, dyeing, leather, tanning processing, sugar manufacturing flourish as clusters. Together with these, the textile industries are huge industrial patrons of waters as 
well as producers of wastewater. The effluent discharged by this industry headed to grim pollution of groundwater and soils and eventually has an effect on the livelihood of the poor (21). During the dying process a significant amount of dyes and other chemicals lost in the wastewater. It is estimated that the dye loses between $10-15 \%$ (22). Dye is generally non-toxic to the environment, but the color waters there may impede high penetration influenced by the aquatic life and the usage limit (23). Decolorization of industrial effluent has been a foremost anxiety in waste water that instigates from textile and dye stuff plant with a unremitting discharge of immense quantity of residual dyes to the environment. A well-organized management of the effluent is an environmental friendly approach for medication of textile effluent. The microbial degradation of dye molecules in the environment is likely to be slow, which signifies that it is promising for high intensity of dye to keep on and probably accumulate. Because of the poor biodegradability of dyes, unadventurous process s of biological treatments is unproductive in the management of dye containing wastewater. Biological decolorization is used in both aerobic and anaerobic environments. A number of reports discourage decolorization of the azo dye by microorganism under anaerobic conditions since it leads to the formation of the corresponding aromatic amines. The efficiency of microbial discolorization depends on the adaptive capacity and activity of selected microorganisms. In recent decades, many microorganisms are capable of degrading azo dyes, including bacteria, fungi and yeast. The discharge of waste water color in the river by the textile industry represents a serious environmental problem and a public health problem. The main part of the wastewater contains azo dyes which are increasingly used in industries because of their ease and cost effective in the synthesis compared with natural dyes. Relative effectiveness of bacteria isolated for decolorization Remazol Black- B clearly implies that these can be effectively used for removing Remazol Black- B from industrial wastewater contaminated. Azoreductase is reported to be the key enzyme expressed in bacterial azo dyes degrading and catalyses the reductive cleavage of the azo bond $(24,20)$. Azoreductase activity had been identified in a number of bacterial species recently, such as Staphylococcus aureus, Shewanella putrefaciens, Shewanella and Pseudomonas spp. (24- 26). It was denoted that enhance in substrate concentration from its best possible level had pessimistic effect on decolorization capacity of isolated isolates. Explorations with distinctive dye concentrations in additional experiments also reported higher net color removal efficiencies at lower dye concentrations (27-29). Dwindle in color removal ability at high substrate concentration might be due to the toxicity of the dye and co contaminants (30). On aromatic ring of azo dye structure one or more sulphonic-acid groups are generally endorse, which might be active as detergents to hold back the growth of microbes (30). One more explanation of the toxicity at elevated concentration may be due to the presence of heavy metals or metal complex dyes and/or the occurrence of non hydrolyzed reactive groups which may impede the bacterial growth (29). In the same way, diminution in color removal at stumpy concentration of the substrate might be due to the shrink in enzyme capability to be acquainted with the substrate proficiently. While in case of diverse carbon sources experimented yeast extract corroborated to be the most excellent amongst tested carbon source. Our results were in accordance with the research performed by Guo et al. (2008), in which the bacterial strains grew well and absolutely decolorized K-2BP where either peptone or yeast extract was contemporary in the medium; however, sucrose, glycerol, glucose, starch and lactose resulted in poorer rates of growth and decolorization of these dyes. Supplementary studies also accounted the utmost color removal of azo dyes in the presence of yeast extract by bacteria (32). In case of variable $\mathrm{pH}$, decolorization was on upper side at $\mathrm{pH}$ 7.5. Whereas at alkaline $\mathrm{pH}$ conditions declined the decolorization efficiency of all the tested isolates. So, from this investigation, it could be bring to a close that neutral $\mathrm{pH}$ sustained bacterial movement to decolorize Remazol Black-B in liquid medium (33-34). Temperature is one more incredibly significant parameter for anaerobic treatment of wastewater. Preferred isolates were mesophilic in nature because they all showed better decolorization in the temperature range upto $35^{\circ} \mathrm{C}$. Similar results were also reported by Guo et al. (2008). The mesophilic choice is conventionally used (35) since it is commonly thought that maintaining high temperature would be extravagant even as degradation within the psychrophilic range is too slow. Overall, one of the selected isolate (1) of bacteria was able to completely remove color of the dye in $18 \mathrm{~h}$. However, these isolates should be tested at large scale treatment system to examine their potential for bioremediation of dye-polluted wastewaters.

\section{CONCLUSION}

The present study divulges that the preferred three isolates can be exploited lucratively for decolorizing Reactive Black B dye. The cultures demonstrated utmost decolorization aptitude at $\mathrm{pH}$ 
between 7.5 for all the three isolates and $35^{\circ} \mathrm{C}$ for $1,2 \& 25^{\circ} \mathrm{C}$ for 3. Moreover, $5 \mathrm{~g} / \mathrm{L}$ yeast extract was found to be optimum for decolorization. In conclusion, bacterial species can be studied further for bioremediation of dye-polluted waters including rate of degradation of azo dyes other than the selected Black dye through an application of bioaugmentation.

\section{ACKNOWLEDGEMENT}

Authors are thankful to Director of IMTECH-CSIR and Director ETL, India for providing facility for culture identification and laboratory respectively.

\section{REFERENCES}

[1] Moorthi PS, Selvam SP, Sasikalaveni A, Murugesan K, Kalaichelvan PT. Decolorization of textile dyes and their effluents using white rot fungi. African JBiotech 2007. 6(4): 424-429.

[2] Rafi F, Fraeankalin W, Cerniglia CE. Appl Environ Microbiol 1990. 56: 2146.

[3] Bhatti HN, Akram N, Asgher M. Optimization of culture conditions for enhanced decolorization of Cibacron Red FN-2BL by Schizophyllum commune IBL-6. Appl Biochem Biotecnol 2008. 149: 255-264.

[4] Abadulla E, Tzanov T, Costa S, Robra K, Cavaco A, Gubitz G. ApplEnviron Microbiol 2000. 66(80): 3357.

[5] Zollinger H. Colour Chemistry Synthesis Properties and Application of Organic Dyes and Pigments 1991. VCH New York pp 92-102.

[6] Pinherio HM, Touraud E, Tomas O Aromatic amines from azo dye reduction: status review with emphasis on direct UV spectrophotometric detection in textile industry wastewater. Dyes Pigments 2004. 61(2): 121-139.

[7] Talarposhti AM, Donnelly T, Anderson G.Color removal from a simulated dye wastewater using a twophase anaerobic packed bed reactor. Water Res 2001.35: 425-432.

[8] Fu Y, Viraraghavan T. Fungal degradation of dye wastewaters: a review. Bioresour Technol 2001. 79: 251-262.

[9] Wong P, Yuen P. Decolorization and biodegradation of Methyl red by Klebsiella pneumoniae RS-13. Water Res 1996. 30(7): 1736-1744.

[10] Stolz A. Basic and applied aspects in the microbial degradation of azo dyes. Appl Microbiol Biotechnol 2001. 56:69-80.

[11] Rajaguru P, Vidya L, Baskarasethupathi B, Kumar PA, Palanivel M, Kalaiselvi K. Genotoxicity evaluation of polluted ground water in human peripheral blood lymphocytes using the comet assay. Mut Res 2002.517: 29-37.

[12] Umbuzeiro GA, Freeman H, Warren SH, Oliveira DP, Terao Y, Watanabe T, Claxton LD.The contribution of azo dyes to the mutagenic activity of the Cristais River. Chemosphere 2005.60: 55-64.

[13] Khehra MS, Saini HS, Sharma DK, Chadha BS, Chimni SS. Biodegradation of azo dye C.I. Acid Red 88 by an anoxic-aerobic sequentialbioreactor. Dyes Pigments 2006.70: 1-7.

[14] Slokar,YM, Le Marechal AM. Methods of decoloration of textile wastewater. Dyes Pigments 1998. 37: 335-356

[15] Bae JS, Freeman HS. Aquatic toxicity evaluation of new direct dyes to the Daphnia magna. Dyes Pigments 2007.73:81-85.

[16] Robinson T, McMullan G, Marchant R, Nigam P. Remediation of dyes in textile effluent: a critical review on current treatment technologies with a proposed alternative (review). Biores Technol 2001.77(3): 247-255.

[17] Chen KC, Wu JY, Liou DJ, Hwang SCJ. Decolorization of the textile azo dyes by newly isolated bacterial strains. J Biotechnol 2003. 101: 57-68.

[18] Hao JJ, FQ Song, F Huang, CL Yang, ZJ Zhang, Y Zheng and XJ Tian. Production of laccase by a newly isolated deuteromycete fungus Pestalotiopsis sp. and its Decolorization of azo dye. Journal of Industrial Microbiology and Biotechnology 2007. 34: 233-240.

[19] Pandey, AP, Singh and L Lyengar. Bacterial decolorization and degradation of azo dyes. International Biodeterioration and Biodegradation 2007.59: 73-84. 
[20] Khalid A.M, Arshad and DE Crowley. Accelerated decolorization of structurally different azo dyes by newly isolated bacterial strains. Applied Microbiology and Biotechnology 2008. 78: 361-369

[21] Jiunkins R. Pretreatment of textile waste water.Proc. 37th Industrial waste Conference Purdue Uni. Lafayette, Ind 1982. p. 37-139

[22] Vaidya AA, Datye KV. Environmental pollution during chemical processing of synthetic fibers. Colourage 1982.14: 3-10

[23] Ajayi SO, Osibanjo O. The state of environment in Nig. Pollution studies of textile industries in Nig. Monogra. Am. Pub. Health Assoc. standard 1980. 1: 76-86.

[24] Nachiyar CV and GS Rajkumar. Puri $\square$ cation and characterization of an oxygen insensitive azoreductase from Pseudomonas aeruginosa. Enzyme and Microbial Technology 2005. 36: 503509.

[25] Li T and JT Guthrie. Colour removal from aqueous soloution of metal complex azo dyes using bacterial cells of Shewanella strain J18 143. Bioresource Technology 2010. 101: 4291-4295

[26] Lin JX, Zhang Z Li, L Lei. Biodegradation of Reactive Blue 13 in a two-stage anaerobic/aerobic fluidized beds system with a Pseudomonas sp. isolate. Bioresource Technology 2010. 101: 3440.

[27] Cruz A. and G Buitron. Biodegradation of Disperse Blue 79 using sequenced anaerobic/aerobic bio $\square$ lters. Water Science and Technology 2010. 44: 159-166.

[28] Kapdan IK. and R Oztekin. Decolorization of textile dyestuff Reactive Orange 16 in fed-batch reactor under anaerobic condition. Enzyme and Microbial Technology 2003. 33: 231-235.

[29] Sponza DT and M Isik. Reactor performances and fate of aromatic amines through decolorization of Direct Black 38 dye under anaerobic/aerobic sequential. Process Biochemistry 2005. 40: 35-44.

[30] Chen KC, JY Wu, DJ Liou and SCJ Hwang. Decolorization of the textile dyes by newly isolated bacterial strains. Journal of Biotechnology 2003.10: 57-68.

[31] Guo J, J Zhou, D Wang, C Tian, P Wang and M Salah Uddin. A novel moderately halophilic bacterium for decolorizing azo dye under high salt condition. Biodegradation 2008.19: 15-19.

[32] Hu TL. Degradation of azo dye RP2B by Pseudomonas luteola. Water Science and Technology 1998. 38: 299-306.

[33] Mali PL, MM Mahajan, DP Patil and MV Kulkarni. Biodecolorisation of members of triphenylmethane and azo groups of dyes. Journal of Scientific and Industrial Research 1999. 59:221-224.

[34] Chang JS, TS Kuo, Y Qu, J Guo, P Wang and H Zhang. Azo dye decolorization with a mutant Escherchia Coli strain. Biotechnology Letters 2000. 22: 807-812

[35] Varel VH, AG Hashimoto and YR Chen. Effect of temperature and retention time on methane production from beef cattle waste. Applied and Environmental Microbiology 1980. 40: 217-222.

[36] Staley, J.R., Boone, A.R., Brenner, D.J., Vos, P.D., Garrity, G.M., Goodfellow, M., Krieg, N.R., Rainey, F.A., Schleifer, K.H., (2001). Bergey's Manual of Determinative Bacteriology, second ed. Springer.

[37] Thomson J D, Gibson T J, Plewniak F, Jeanmougin F, Higgins D G, (1997). The ClustalX windows interface: flexible strategies for multiple sequence alignment aided by quality analysis tools. Nucleic Acids Research, 25(24): 4876-4882. 